\title{
ADOPSI MERUPAKAN CARA PEMBERIAN STATUS HUKUM TERHADAP ANAK LUAR KAWIN DI DESA PAKRAMAN BUKIT TUMPENG KECAMATAN SELEMADEG BARAT KABUPATEN TABANAN \\ (Perspektif Hukum Adat Bali)
}

\author{
Oleh
}

I Gede Putu Mantra

Dosen IHDN Denpasar

\begin{abstract}
Abstaksi
Penelitian ini bersifat penelitian hukum empiris yang mencoba untuk memperoleh gambaran tentang latarbelakang pengangkatan anak dalam masyarakat Hukum Adat Bali, khususnya pengangkatan anak luar kawin.

Dalam kepercayaan masyarakat Hukum Adat Bali, Arti penting seorang anak lahir dalam sebuah keluarga, dimana seorang anak (putra) akan dapat menyeberangkan orang tuanya dari neraka. Setiap pasangan suami-istri mempunyai naluri untuk mempunyai seorang anak. Akan tetapi tidak semua perkawinan berhasil mengadakan keturunan. Untuk mengatasi hal tersebut dalam masyarakat hukum adat Bali dapat dilakukan dengan cara mengangkat anak, anak yang diangkat diusahakan berasal dari lingkungan keluarga. Disamping itu bisa juga anak yang diangkat berasal dari luar lingkungan keluarga dan anak luar kawin dengan alasan tertentu.

Tidak semua pengangkatan anak didasarkan pada latarbelakang, pasangan suami-istri (keluarga) tidak memiliki keturunan, akan tetapi ada beberapa kasus pengangkatan anak dalam masyarakat Hukum Adat Bali khususnya di Desa Pakraman Bukit Tumpeng didasarkan pada alasan untuk menyelamatkan status anak yang lahir di luar perkawinan yang sah, disamping itu karena adanya rasa belas kasihan.
\end{abstract}

Kata Kunci: pengangkatan Anak, anak luar kawin, status hukum

\section{PENDAHULUAN}

\subsection{Latar Belakang.}

Setiap perkawinan pada dasarnya menginginkan adanya keturunan yang dapat meneruskan silsilah orang tua atau generasi dari keluarga yang bersangkutan. Suatu perkawinan dapat dikatakan belum sempurna apabila pasangan suami istribelum memperoleh keturunan, karena anak mempunyai kedudukan yang sangat penting dalam keluarga, disamping hal tersebut merupakan tujuan dari perkawinan.

Zaini. M (1992) menyatakan, bahwa "keinginan untuk mempunyai anak adalah naluri manusia. Akan tetapi tidak semua perkawinan berhasil mengadakan keturunan". Untuk mengatasi hal tersebut dalam masyarakat hukum adat Bali dapat dilakukan dengan cara mengangkat anak. Perbuatan mengangkat anak pada dasarnya adalah pengambilan anak orang lain ke dalam keluarga sendiri, sehingga orang yang mengangkat anak dengan anak yang diangkat timbul suatu hubungan kekeluargaan yang sama seperti hubungan antara orang tua dengan anak kandung.

Menurut Korn, VE (dalam Windia dan Sudantra, $2006: 96$ ), ada beberapa istilah untuk menyebut Pengangkatan anak yaitu antara lain: "ngidih pianak, nyentanayang, mgedeng/ ngengge pianak, angkat anak dan meras pianak. Sedangakan anak yang diangkat itu disebut sentana, anak ban ngidih, anak sumendi, anak pupon-pupon dan sentana peperasan".

Dalam masyarakat hukum adat Bali, sedapat mungkin diusahakan anak yang akan 
diangkat berasal dari keluarga purusa terdekat. apabila dalam keluarga purusa terdekat tidak ada, maka dicari dari keluarga yang lebih jauh, mengingat hukum kekeluargaan di Bali berdasarkan sistem patrilineal yaitu hubungan seorang anak dengan keluarga bapaknya menjadi dasar tunggal bagi susunan keluarganya. Keluarga dari bapak atau keluarga dari pancar laki-laki (purusa) adalah yang paling utama. Hal ini terkait dengan kepercayaan, bahwa anak laki-lakilah yang nantinya dapat membebaskan roh orang tuanya dan leluhurnya dari neraka.

Menurut Titib, Kata anak dalam bahasa sansekerta di sebut "putra". Kata "putra" pada mulanya berarti kecil atau yang di sayang, kemudian kata ini dipakai untuk menjelaskan mengapa pentingnya seorang anak lahir dalam keluarga : Oleh karena seorang anak yang akan menyeberangkan orang tuanya dari neraka yang disebut Put (neraka lantaran tidak memiliki keturunan), oleh karena itu ia disebut Putra. Putra juga sama artinya dengan "sunu, atmaja, atmansambhava, nandana, kumara dan samtana". kata samtana ini lah yang di Bali menjadi sentana yang berarti keturunan (Titib, I Made, 2003 : 29).

Tidak semua perbuatan pengangkatan anak dilatarbelakangi oleh adanya pasangan suamiistri (keluarga) yang tidak memiliki keturunan, akan tetapi ada beberapa kasus pengangkatan anak di Bali khususnya di Desa Pakraman Bukit Tumpeng didasarkan pada alasan untuk menyelamatkan status anak yang lahir di luar perkawinan yang sah, disamping itu karena adanya rasa belas kasihan.

\section{PEMBAHASAN \\ 2.1 Pengertian a.Penggangkatan Anak}

Pasal. 1 butir 9 UU. No. 35 Tahun 2014 menyebutkan, bahwa:

"Anak angkat adalah anak yang haknya dialihkan dari lingkungan kekuasaan orang tua, wali yang sah atau orang lain yang bertanggungjawab atas perawatan, pendidikan dan membesarkan anak tersebut ke dalam lingkungan keluarga orang tua angkatnya berdasarkanputusan atau penetapan pengadilan".

Sedangkan Hilman Hadikusuma, (dalam Setiady, Tolib, 2009 : 215) menyatakan bahwa "Anak Angkat adalah anak orang lain yang dianggap anak sendiri oleh orang tua angkat dengan resmi menurut hukum adat setempat dikarenakan tujuannya untuk melangsungkan keturunan dan atau pemeliharaan atas harta kekayaan rumah tangga".

\section{b. Anak Angkat dan Anak Luar Kawin}

Hukum Adat Bali mengklasifikasikan status anak dalam dua golongan yaitu anak sah dan anak tidak sah. Anak sah mempunyai hubungan hukum dengan kedua orang tuanya. Dalam masyarakat Bali anak yang lahir di luar perkawinan sah lazim disebut bebinjat dan astra.

Korn mengaburkan pengertian bebinjat dan astra, yaitu dengan menyamakan pengertian keduanya. Menurut Pangkat, I Gde Wayan, anak astra tidak sama dengan anak bebinjat. Anak bebinjat adalah anak yang ayah biologisnya sama sekali tidak diketahui, sedangkan anak astra adalah anak yang ayah biologisnya diketahui, tetapi anak itu lahir sebelum upacara perkawinan dilaksanakan. Apabila si ayah kemudian mengawini ibunya sebagaimana mestinya, maka si anak bisa berstatus sebagai anak sah. Apabila si ayah tidak mengawini ibunya dengan sebagaimana mestinya, maka anak tersebut tetap berstatus sebagai anak astra. (Windia dan Sudantra, 2006 : 104).

Anak sendiri yang lahir tidak melalui perkawinan yang sah tidak dikenal sebagai anak sah, melainkan anak yang tidak sah. Anak yang tidak sah dapat dibedakan menjadi dua jenis, yaitu: a. Anak luar kawin atau anak bebinjat (menurut hukum adat) dan disebut sebagai anak yang lahir dari hubungan dengan seseorang wanita yang tidak dinikahi. Anak ini tidak berhak menduduki tempat sebagai ahli waris.

b. Anak astra yaitu anak yang lahir sebagai akibat hubungan perkawinan yang tidak sederajat. Pengertian anak astra ini dalam hubungan adat, terdapat dua pengertian, yaitu anak luar kawin juga disebut anak astra, dan anak yang lahir dari hubungan yang tidak sederajatpun juga dianggap sebagai anak astra (Pudja, 1977:92).

Dalam masyarakat dikenal istilah anak sah dan anak tidak sah. Anak sah adalah anak yang dilahirkan dari perkawinan yang sah, terlepas dari apakah anak tersebut belum ada atau sudah ada dalam kandungan pada waktu upacara pengesahan perkawinan dari kedua orang tuanya dan lahir anak maka anak tersebut adalah anak sah. Sedangkan anak tidak sah adalah yang dilahirkan dari orang yang tidak pernah kawin sah sehingga kedudukan hukumnya hanya pada ibu dan keluarga ibunya. 


\subsection{Faktor-Faktor Yang Melatarbelakangi Pengangkatan Anak Luar Kawin Di Desa Pakraman Bukit Tumpeng, Kecamatan Selemadeg Barat, Kabupaten Tabanan}

Salah satu tujuan dari perkawinan bagi masyarakat Umat Hindu di Bali adalah untuk mendapatkan atau memperoleh keturunan dengan maksud agar dapat meneruskan warisan orang tua atau keluarganya. Akan tetapi tidak sedikit perkawinan gagal untuk memperoleh keturunan yang diharapkan dapat meneruskan hak dan kewajiban orang tuanya. Untuk mengatasi agar tidak sampai putusnya generasi dari keluarga tersebut, maka sering dilakukan dengan cara mengangkat anak oleh pasangan suami-istri yang tidak mempunyai keturunan. Disamping itu pengangkatan anak dapat juga dilakukan oleh pasangan suami-istri yang sudah mempunyai keturunan dengan pertimbangan-pertimbangan tertentu.

Dalam Undang-Undang No. 14 Tahun 1979 tentang Kesejahteraan Anak di sebutkan, bahwa "pengangkatan anak harus dilaksanakan dengan mengutamakan kepentingan kesejahteraan anak". Sedangkan Undang-Undang No. 35 Tahun 2014 tentang Perubahan Atas Undang-Undang No. 23 Tahun 2002 tentang Perlindungan Anak menyebutkan, " pengangkatan anak hanya dapat dilakukan untuk kepentingan yang terbaik bagi anak dan dilakukan berdasarkan adat kebiasaan setempat dan ketentuan peraturan perundangundangan".

Berbeda dengan pengangkatan anak yang disebutkan dalam peraturan perundang-undangan, tujuan "pengangkatan anak dalam hukum adat lebih ditekankan pada kekhawatiran dari calon orang tua angkat akan kepunahan atau putungnya keluarga tersebut, maka calon orang tua angkat (yang tidak memiliki anak) mengambil anak dari lingkungan kerabatnya, dan berkedudukan sebagai anak kandung dari ibu dan bapak yang mengangkatnya, terlepas dari golongan sanak saudaranya semula" (Kamil, dkk, 2008 : 34).

Menurut Zaini (1992: 61), alasan pengangkatan anak menurut hukum adat antara lain:

a. Tidak mempunyai anak. Hal ini merupakan alasan yang bersifat umum karena satu-satunya cara bagi mereka yang belum atau tidak mempunyai anak dengan mengangkat anak sebagai pelengkap kebahagiaan dan kelengkapan serta menyemarakkan rumah tangga.

b. Rasa belas kasihan terhadap anak-anak tersebut disebabkan orang tua si anak tidak mampu memberikan nafkah kepadanya. Hal ini merupakan alasan yang sangat positif karena membantu anak juga membantu beban orang tua kandung si anak asal didasari oleh kesepakatan yang ikhlas antara orang tua angkat dan orang tua kandung.

c. Belas kasihan karena anak tersebut tidak mempunyai orang tua. Hal ini merupakan suatu kewajiban moral bagi yang mampu sebagai misi kemanusiaan.

d. Hanya mempunyai anak laki-laki maka diangkatlah anak perempuan atau sebaliknya. Hal ini merupakan alasan yang logis karena umumnya orang ingin mempunyai anak perempuan dan anak laki-laki.

e. Sebagai pemancing bagi yang tidak mempunyai anak, untuk dapat mempunyai anak kandung. Alasan ini berhubungan erat dengan kepercayaan yang ada pada sementara anggota masyarakat.

f. Untuk menambah jumlah keluarga. Hal ini karena orang tua angkatnyamempunyai banyak kekayaan.

g. Dengan maksud agar anak yang diangkat mendapat pendidikan yang baik. Alasan ini erat hubungannya dengan misi kemanusiaan.

h. Faktor kekayaan. Dalam hal ini disamping alasan sebagai pemancing untuk dapat mempunyai anak kandung, juga sering pengangkatan anak ini dalam rangka untuk mengambil berkat baik bagi orang tua angkatnya maupun anak yang diangkat demi bertambah baiknya kehidupan mereka.

i. Untuk menyambung keturunan dan mendapatkan ahli waris bagi yang tidak mempunyai anak kandung.

j. Adanya hubungan keluarga sehingga orang tua kandung si anak tersebut meminta suatu keluarga supaya anak tersebut dijadikan anak angkat. Hal ini juga mengandung misi kemanusiaan.

k. Diharapkan anak dapat menolong di hari tua dan menyambung keturunan bagi yang tidak mempunyai anak. Dari sini terdapat alasan timbal balik antara kepentingan si anak dan jaminan masa tua bagi orang tua angkatnya.

1. Ada perasaan kasihan atas nasib anak yang tidak terurus. Pengertian tidak terurus dapat berarti orang tuanya masih hidup namun tidak mampu atau tidak bertanggung jawab sehingga anaknya menjadi terkatung-katung. Disamping itu dapat dilakukan terhadap anak yang orang tuanya sudah meninggal dunia.

m. Untuk mempererat hubungan keluarga. Disini terdapat misi untuk mempererat pertalian famili dengan orang tua si anak angkat. 
n. Anak kandung sakit-sakitan atau meninggal dunia sehingga untuk menyelamatkan si anak, anak tersebut diberikan kepada keluarga atau orang lain yang belum atau tidak mempunyai anak dengan harapan anak yang bersangkutan akan selalu sehat dan panjang usia (Zaini, 1992 :61).

Sedangkan menurut Hukum Adat Bali tujuan dari pengangkatan anak adalah sebagai berikut:

1. Meneruskan warisan. Menurut ajaran agama Hindu yang tercemin dalam hukum adat Bali bahwa yang dimaksud dengan warisan adalah segala kewajiban (swadharma) dan hak, baik dalam hubungannya dengan aspek parahyanagan, pawongan maupun palemahan. Dengan demikian, anak angkat tidak saja berhak mewarisi harta benda orang tua angkatnya, tetapi juga memiliki kewajiban sebagai seorang anak yang sama dengan anak kandung. Kewajiban itu misalnya memelihara merajan dan tempat suci lainya warisan orang tua angkatnya termasuk melakukan persembahan terhadap roh para leluhur orang tua angkatnya (parahyangan), mensucikan orang tua angkatanya atau roh leluhurnya (upacara ngaben), melaksanakan kewajiban dengan anggota keluarga yang lain dan dalam kaitanya dengan sesoroh, banjar (pawongan) dan memelihara rumah, lingkungan milik orang tua yang mengangkatnya (palemahan).

2. Menyelamatkan roh leluhur. Dengan adanya anak angkat maka sebuah keluarga tidak mengalami putung atau putus. Dalam kepercayaan Hindu, keturunan yang berlanjut ini dapat menyelamatkan roh para leluhur. Dalam adi parwa menyebutkan tentang pentingnya keturunan untuk menyelamatkan roh para leluhur. Melihat hal di atas, betapa pentingnya kehadiran seorang anak dalam keluarga sebagai penerus keturunan dan dapat menyelamatkan roh para leluhur dari neraka. Dalam Manawadharmasastra IX.138 disebutkan karena anak laki-laki akan mengantarkan pitara dari neraka yang disebut put, karena itu ia di sebut putra dengan kelahirannya sendiri (Puja dan Tjokorda Rai Sudharta, 1973 : 564). Sedangkan dalam Adiparwa, 74,38 disebutkan seseorng dapat menundukan dunia dengan lahirnya anak ia memperoleh kesenangan yang abadi, memperoleh cucu-cucu dan kakek-kakek akan memeperoleh kebahagiaan yang abadi dengan kelahiran cucu-cucunya.
3. Pengikat tali kasih keluarga. Kelahiran seorang anak dalam keluarga dapat sebagai pengingkat tali kasih dalam keluarga, hal ini sebutkan dalam Adiparwa, seorang anak merupakan pengikat tali kasih yang sangat kuat dalam keluarga, ia merupakan pusat penyatunya cinta kasih orangtuanya. Dalam ajaran agama Hindu dapat dikatakan kehadiran seorang anak dapat sebagai penjalin cinta kasih dan menciptakan kedamaian dalam keluarga.(https// paduarsana.com/2013/05/15.mengadopsianak-dalam perspektif-adat-bali)

Windia dan Sudantra (2006: 96) dalam bukunya Pengantar Hukum Adat Bali menyebutkan ada beberapa Motif utama pengangkatan anak dalam masyarakat hukum adat Bali yaitu, 1) untuk mendapatkan anak sebagai pelanjut keturunan, 2) sebagai penuntun lahirnya anak kandung, 3) penyelamatan status anak luar kawin, 4) untuk menggantikan kewajiban kemasyarakatan (ayahan) di desa/banjar.

Berdasarkan hasil penelitian menggambarkan, bahwa tidak jauh berbeda dengan alasan pengangkatan anak di atas, tindakan pengangkatan anak dalam masyarakat hukum adat di Bali khususnya di Desa Pakraman Bukit Tumpeng, Kecamatan Selemadeg Barat, Kabupaten Tabanan didasarkan atas beberapa pertimbangan :

1. Pasangan suami-istri yang melakukan pengangkatan anak tidak mempunyai anak.

2. Kekawatiran pada saat orang tua meninggal dunia tanpa mempunyai anak yang menyebabkan kehilangan garis keturunannya sendiri.

3. Belas kasihan anak yang bersangkutan tidak mempunyai orang tua (yatim piatu) atau tidak jelas orang tuanya.

5. Untuk menyambung garis keturunan dan mendapatkan regenerasi bagi suami-istri yang tidak mempunyai anak.

8. Diharapkan anak yang di angkat dapat menolong/memelihara orang tua angkatnya di hari tua. Dari sini terdapat motivasi timbal balik antara kepentingan anak dan jaminan masa tua bagi orang tua angkat.

9. Untuk dapat menggantikan peranan dan kewajiban kehidupan orang tua angkat, baik materiil maupun immateriil dalam hubungan dengan kewajiban Prahyangan, Pawongan, dan Palemahan. (Buktika, I Nyoman, Wawancara tanggal,13 Maret 2016) 
Sedangkan yang menjadi alasan mendasar dalam Pengangkatan Anak luar kawin di Desa Pakraman Bukit Tumpeng, Kecamatan Selemadeg Barat, Kabupaten Tabanan didasarkan pada pertimbangan-pertimbangan sebagai berikut:

a. Karena rasa belas kasihan yang disebabkan anak yang bersangkutan tidak mempunyai orang tua (yatim piatu) atau tidak jelas orang tuanya. Ini merupakan suatu kewajiban moral bagi setiap orang yang mampu dari segi ekonomi untuk membantu anak yang kurang beruntung/ mampu, dengan harapan anak yang diangkat akan mendapatkan pendidikan dan kehidupan yang layak nantinya.

b. Untuk memberikan status/kedudukan yang jelas kepada anak luar kawin. Dengan tindakan mengangkat anak tersebut, maka status anak luar kawin sama kedudukannya seperti anak kandung (Buktika, I Nyoman, Wawancara tanggal 13 Maret 2016)

Hal senada juga disampaikan oleh Mudiarta, bahwa

Pada dasarnya kelahiran anak luar kawin merupakan kelahiran yang tidak dikehendaki, karena hal tersebut dianggap aib bagi keluarga dan masyarakat. Anak yang lahir di luar perkawinan yang sah hanya memiliki hubungan hukum dengan ibu yang melahirkannya. Untuk menyelamatkan anak dan ibu yang melahirkannya, maka pihak keluarga cendrung mengambil tindakan dengan cara mengangkat anak tersebut yang diakui sebagai anaknya sendiri. Pengangkatan ini biasanya dilakukan oleh saudara atau oleh ayah dari ibu yang melahirkan anak tersebut. Oleh karena itu tujuan utama dari pengangkatan anak luar kawin di Desa Pakraman Bukit Tumpeng, Kecamatan Selemadeg Barat, Kabupaten Tabanan adalah untuk menyelamatkan status dari anak tersebut (Mudiarta, I Ketut, wawancara tanggal 12 Maret 2016).

\subsection{Proses Pengangkatan Anak Luar Kawin Menurut HukumAdat Di Desa Pakraman Bukit Tumpeng, Kecamatan Selemadeg Barat, Kabupaten Tabanan}

Terwujudnya keluarga yang bahagia dan sejahtera salah satunya karena hadirnya seorang anak dalam keluarga tersebut. Namun sebagaimana diketahui tidak semua suami istri bisa melahirkan anak, sehingga hal ini sering memicu retaknya perkawinan dalam keluarga. Dengan kondisi yang seperti itu, tidak sedikit rusaknya rumah tangga akibat mereka tidak mempunyai anak (keturunan).
Menurut Titib, Kata anak dalam bahasa sansekerta di sebut "putra". Kata "putra" pada mulanya berarti kecil atau yang di sayang, kemudian kata ini dipakai untuk menjelaskan mengapa pentingnya seorang anak lahir dalam keluarga : Oleh karena seorang anak yang akan menyeberangkan orang tuanya dari neraka yang disebut Put (neraka lantaran tidak memiliki keturunan), oleh karena itu ia disebut Putra. Putra juga sama artinya dengan "sunu, atmaja, atmansambhava, nandana, kumara dan samtana". kata samtana ini lah yang di Bali menjadi sentana yang berarti keturunan (Titib, I Made, 2003 : 29)

Menurut Korn, VE (dalam Windia dan Sudantra, 2006 : 96), ada beberapa istilah untuk menyebut Pengangkatan anak yaitu antara lain: "ngidih pianak, nyentanayang, mgedeng/ngengge pianak, angkat anak dan meras pianak. Sedangakan anak yang diangkat itu disebut sentana, anak ban ngidih, anak sumendi, anak pupon-pupon dan sentana peperasan".

Menurut hukum adat Bali tidak ada peraturan kapan dan umur berapa anak boleh diangkat. Untuk menghindari terjadinya hambatan atau konflik dalam proses pengangkatan anak, menurut Dyatmikawati (2008) secara sederhana proses pengangkatan anak dapat di gambarkan sebagai berikut:

1) Dimulai dari rembug keluarga kecil (pasangan suami-istri yang akan mengangkat anak). Kemudian diajukan dengan rembug keluarga yang lebih luas meliputi saudara kandung yang lainnya.setelah ada kesepakatan matang, lalu mengadakan pendekatan dengan orng tua atau keluarga yang anaknya mau diangkat.

2) Setelah semua jalan lancar, dilanjutkan dengan pengumuman (pasobyahan) dalam rapat desa atau banjar. Tujuanya, untuk memastikan tidak ada anggota keluarga lainnya dan warga desa atau banjar yang keberatan atas pengangkatan anak yang diamksud. Oleh karena itu, anak angkat harus diusahakan dari lingkungan keluarga yang terdekat, garis purusa, yang merupakan pasidikarya. Ada tiga golongan pasidikarya yaitu pasidikarya waris (mempunyai hubungan saling waris), pasidikarya sumbah (pempunyai hubungan saling menyembah leleuhur), dan pasidikarya idih pakidih (mempunyai hubungan perkawinan).

3) Apabila tidak ada garis dari garis purusa, maka dapat dicari dari keluarga menurut garis pradana (garis ibu). Apa bila tidak ditemuakn 
pula maka dapat diusahakan dari keluarga lain dalam satu soroh dan terakhir sama sekali tidak ada, pengangkatan anak dapat dilakukan walaupun tidak ada hubungan keluarga (sekama-kama).

4) Anak yang diangkat wajib beragama Hindu. Jika yang diangkat seseorng yang bukan umat Hindu, pengangkatan anak itu akan ditolak warga desa karena tujuan pengangkatan anak antara lain untuk meneruskan warisan baik dalam bentuk kewajiban maupun hak, termasuk berbagai kewajiban desa adat, terutama dalam hubungan dengan tempat suci (pura).

5) Melakukan upacara pemerasan yang disaksikan keluarga dan prangkat pemimpin desa atau banjar adat. Pengangkatan anak baru di pandang sah sesudah dilakukan upacara pemerasan. Itulah sebabnya anak angkat itu disebut pula dengan istilah sentana paperasan.

6) Selain melakukan upacara pemerasan proses berikutnya adalah pembuatan surat sentana. Walaupun hal ini tidak merupakan syarat bagi sahnya pengangkatan anak, tetapi hal ini penting dilakukan sebagai alat bukti bahwa telah terjadi pengangkatan anak. Menurut hukum positif pengangkatan anak dilakukan dengan penetapan hakim. Dengan demikian sesudah upacara pemerasan, patut dilanjutkan dengan mengajukan pemohonan penetapan pengangkatan anak kepada Pengadilan Negeri dalam daerah hukum tempat pengangkatan anak itu dilaksanakan (https:// suryawanhindudharma.wordpress.com).

Berdasarkan hasil penelitian yang dilakukan di Desa Pakraman Bukit Tumpeng diketemukan bahwa:

Dalam pengangkatan anak diutamakan dari keluarga dekat misalnya anak dari adik lakilaki maupun dari kakak kandung laki-laki, tetapi bila dari keluarga dekat tidak ada maka dari keluarga yang lebih jauh misalnya dari saudara misan yang masih dalam lingkungan keluarga purusa, dan apabila dari keluarga purusa tidak ada, bisa dari keluarga pihak perempuan atau diambil dari orang yang tidak mempunyai hubungan darah.Pengangkatan anak luar kawin di Desa Pakraman Bukit Tumpeng, dilakukan oleh kalangan keluarga seperti : paman ataupun kakek dari anak tersebut. Pengangkatan anak (adopsi) di Desa Pakraman Bukit Tumpeng, dilakukan dengan cara terang dan tunai, terang artinya pengangkatan anak dilakukan sepengetahuan perangkat desa Pakraman dan desa dinas serta keluarga, sedangkan tunai adalah pengangkatan anak harus dilengkapi dengan upacara agama yaitu berupa upacara meras/widiwidana (Suendra, I Putu, wawancara tanggal 20 Maret 2016).

Walaupun alasan yang mendasar tentang pengangkatan anak luar kawin adalah untuk menyelamatkan anak dan ibunya serta nama baik keluarga, maka tetap memperhatikan tentang proses Pengangkatan anak yang berlaku di Desa Pakraman Bukit Tumpeng, Kecamatan Selemadeg Barat, Kabupaten Tabanan adalah sebagai berikut:

1. Melakukan rapat keluarga. Hal ini dilakukan dalam keluarga yang akan mengangkat anak dan keluarga besar termasuk di dalamnya melibatkan ibu dari anak tersebut.

2. Melakukan pengumuman (pasobyahan) dalam rapat desa atau banjar. Pengumuman ini dimaksudkan untuk memberitahukan kepada masyarakat bahwa akan ada perbuatan hukum pengangkatan anak di lingkungan banjar/desa mereka.

3. Setelah dilakukan pengumuman (pasobyahan) dalam rapat desa atau banjar, maka dilakukan upacara widiwidana/pemerasan yang dipuput oleh rohaniawan dan di saksikan oleh keluarga dan Prajuru Desa Adat setempat.

4. Setelah upacara widiwidana/pemerasan selesai, dilanjutkan dengan mengajukan pernohonan penetapan tentang pengangkatan anak luar kawin tersebut kepada pengadilan negeri di daerah Hukum tempat pengangkatan anak dilaksanakan untuk mendapatkan kepastian hukum (Suendra, I Putu, wawancara tanggal 20 Maret 2016).

Menurut Suparta, I Wayan (wawancara tanggal 19 Maret 2016) menyatakan, bahwa :

Pengangkatan anak luar kawin di Desa Pakraman Bukit Tumpeng, Kecamatan Selemadeg Barat, Kabupaten Tabanan dilakukan oleh orang yang masih berada dalam lingkungan keluarga, dimana pengangkatan anak tersebut dilakukan oleh kakak dari ibu yang melahirkan anak tersebut (paman), rembuk keluarga tetap masih diperlukan untuk menghindari hal-hal yang tidak diinginkan dikemudian hari mengingat pengangkatan anak luar kawin membawa akibat hukum dimana kedudukan anak tersebut sama seperti anak kandung. Pendekatan terhadap ibu yang melahirkan tidak begitu diperlukan karena posisinya yang lemah sehingga segalanya diserahkan pada keputusan keluarga, akan tetapi pendekatan tetap dilakukan (diajak 
bicara) karena motifutama dari pengangkatan anak luar kawin adalah untuk menyelamatkan status anak tersebut dan ibu yang melahirkannya, serta nama baik keluarga.

Dari penjelasan di atas, maka proses pengangkatan anak luar kawin di Desa Pakraman Bukit Tumpeng, Kecamatan Selemadeg Barat, Kabupaten Tabanan pada dasarnya mengikuti proses pengangkatan anak pada umumnya yang berlaku pada masyarakat setempat mengingat perbuatan hukum pengangkatan anak akan memberikan status hukum seperti anak kandung bagi anak yang diangkat.

\subsection{Kedudukan Anak Luar Kawin Yang Diangkat Sah sebagai Anak Menurut Hukum Adat Bali}

Masyarakat hukum adat Bali mengenal dua macam istilah untuk menyebut anak luar kawin yaitu anak bebinjat dan anak astra. Pengertian anak astra ini disebutkan bahwa anak yang dilahirkan dari hubungan yang tidak sah antara seorang laki-laki bangsawan dengan seorang wanita biasa. Atau ada yang menyebut pengertian anak astra adalah anak yang terlahir diketahui siapa ayahnya tetapi kedua orang tua biologisnya tersebut belum terikat dalam perkawinan yang sah atau ketika upacara perkawinan dilangsungkan si istri diketahui telah mengandung sehingga anak yang dilahirkan dianggap anak astra (anak luar kawin). Akan tetapi tidak semua daerah di Bali memandang hal tersebut di atas sebagai anak astra. Untuk menghindari aib keluarga, maka ketika calon istrinya diketahui sudah mengandung maka pihak keluarga akan mengambil tindakan untuk mendorong anaknya segera melangsungkan perkawinan, sehingga anak yang dikandung akan lahir sebagai anak sah, cara ini ditempuh untuk menyelamatkan status anak tersebut.

Menurut Windia dan Sudantra (2006 : 98). Upacara mepamit secara hukum memutuskan hubungan hukum antara anak tersebut dengan orang tua dan sanak keluarga asalnya sehingga anak tersebut tidak lagi terikat dengan hak dan kewajiban sebagai anak dalam keluarga asalnya tersebut, termasuk dalam hubungan waris. Dengan upacara meperas maka antara anak tersebut dengan keluarga orang tua angkat timbul hubungan hukum kekeluargaanyang sama seperti hubungan hukum yang diakibatkan oleh hubungan darah, yaitu sama seperti anak kandung.

Dalam Hukum Hindu ditegaskan bahwa kedudukan anak angkat tidak berbeda dengan anak kandung. Hal ini disebutkan dalam Manawadharmasastra IX.141 sebagai berikut: "Jika anak laki yang mempunyai anak angkat lakilaki yang mempunyai sifat-sifat mulia yang sama akan mewarisi walaupun lahir dari keluarga yang lain" (Puja dan Tjokorda Rai sudharta, 1973:554565). Lebih lanjut dalam Manawadharmasastra IX.142 juga disebutkan, bahwa "keluarga dan harta warisan dari orang tua yang sebenarnya. Tarpana (upacara persembahan kepada orang tua yang meningal), ia arus mengikuti nama keluarga (yang mengangkat) serta menerima warisan dari orang tua angkat (setelah tarpana kepadanya)" (Puja dan Tjokorda Rai sudharta,1973 : 565).

Berdasarkan hasil penelitian di Desa

Pakraman Bukit Tumpeng, kecamatan Selemadeg Barat, Kabupaten Tabanan juga menggambarkan, bahwa "pengangkatan anak luar kawin yang dilakukan melalui proses pengangkatan anak menurut hukum adat setempat memiliki kedudukan yang sama sebagai anak kandung dari orang tua angkatnya dengan segala hak dan kewajiban sebagaimana berlaku sebagai anaknya sendiri" (Buktika, I Nyoman, Wawancara, tanggal 13 Maret 2016).

Sedangkan Wayan Suparta mengemukakan bahwa:

Dengan mengangkat anak luar kawin melalui proses yang berlaku dalam hukum adat, maka anak yang bersangkutan menjadi anak sah. Sehingga hal ini berpengaruh terhadap kedudukan hukum anak luar kawin tersebut terhadap orang tua angkatnya seperti, hak mewaris dan kewajiban untuk memelihara orang tua angkatnya setelah tidak mampu lagi serta melaksanakan pengabenan setelah orang tuanya meninggal dunia (wawancara, 19 Maret 2016).

Disamping itu menurut Mudiarta, I Ketut mengemukakan, bahwa :

pada dasarnya pengangkatan anak luar kawin merupakan salah satu upaya untuk menyelamatkan status anak luar kawin dan ibu yang melahirkannya, sehingga pengangkatan anak luar kawin dilakukan oleh pihak keluarga. Dengan pengangkatan (adopsi) anak luar kawin sesuai dengan tata cara/proses hukum adat setempat, maka anak luar kawin yang diangkat sah sebagai anak oleh orang tua angkatnya akan mempunyai kedudukan yang sama seperti anak kandung sendiri. Dengan demikian, maka anak luar kawin yang diangkat sah sebagai anak oleh orang tua angkatnya mempunyai segala hak dan kewajiban dalam hubungannya dengan aspek parahyangan seperti : memelihara merajan dan tempat suci lainya, termasuk menyembah roh 
para leluhur orang tua angkatnya, pawongan seperti : melaksanakan upacara pengabenan ketika orang tua angkatnya telah meninggal dunia, melaksankan ayahan desa/banjar, dan palemahan yaitu memelihara rumah, lingkungan milik orang tua yang mengangkatnya (Wawancara tanggal 12 Maret 2016).

Dari uraian tersebut di atas, anak luar kawin yang diangkat sah sebagai anak memiliki kedudukan yang sama dengan anak kandung. Hal ini tentu memiliki akibat hukum terhadap hukum kekeluargaan. Dalam hukum adat Bali tujuan pengangkatan anak adalah untuk meneruskan swadharma yang berhubungan dengan parhyangan, pawongan dan palemahan baik terhadap keluarga maupum masyarakat (desa pakraman).

\section{PENUTUP}

\subsection{Simpulan}

Berdasarkan pembahasan diatas, maka dapat disimpulkan beberapa hal sebagai berikut : 1. Pengangkatan Anak luar kawin di Desa Pakraman Bukit Tumpeng, didasarkan pada pertimbangan rasa belas kasihan, untuk menyelamatkan anak dan ibu yang melahirkannya, serta untuk memberikan status/ kedudukan yang jelas kepada anak yang lahir di luar perkawinan yang sah.

2. Proses Pengangkatan anak luar kawin di Desa Pakraman Bukit Tumpeng adalah dimulai dengan rapat keluarga, dilanjutkan dengan pengumuman (pasobyahan) dalam rapat desa atau banjar, kemudian diadakan upacara widiwidana/upacara pemerasan yang dipuput oleh rohaniawan dan di saksikan oleh keluarga dan prajuru desa adat, dilanjutkan dengan mengajukan pernohonan penetapan tentang pengangkatan anak luar kawin tersebut kepada pengadilan negeri di daerah hukum tempat pengangkatan anak dilaksanakan untuk mendapatkan kepastian Hukum.

3. Kedudukan anak luar kawin yang diangkat sah memiliki kedudukan yang sama seperti anak kandung dari orang tua yang mengangkatnya dengan segala hak dan kewajiban sebagaimana anaknya sendiri.

\subsection{Saran}

Berdasarkan atas hasil penelitian yang di atas, maka dapat dikemukakan saran-saran sebagai berikut :

a. Pengangkatan Anak luar kawin walaupun telah dianggap sah menuruthukum adat(Hukum Adat Bali), demi kepastian hukum hendaknya tetap dimintakan penetapan kepada pengadilan negeri di wilayah hukum tempat dimana pengangkatan anak luar kawin dilaksanakan.

b. Masyarakat khususnya generasi muda hendaknya bisa berfikir jernih untuk tidak melakukan hubungan suami-istri di luar perkawinan sehingga tidak ada anak-anak yang lahir di luar perkawinan yang sah.

c. Untuk lembaga-lembaga umat (Hindu) hendaknya lebih intensif memberikan pencerahan agama, etika dan moral kepada masyarakat khususnya generasi muda.

\section{DAFTAR PUSTAKA}

Abdulkadir Muhhamad, 2004, Hukum dan Penelitian Hukum, Bandung, Pt. Citra Aditya Bakti.

Kamil, Ahmad dan Fauzan, 2008, Hukum Perlindungan Dan Pengangkatan Anak Di Indonesia, Jakarta: PT. Raja Grafindo Persada.

Mantra, I Gede Putu, 2016, Laporan Penelitian Pengangkatan Anak Luar Kawin Di Desa Pakraman Bukit Tumpeng, Kecamatan Selemadeg Barat, Kabupaten Tabanan, IHDN Denpasar

Pudja, Gede, 1977, Hukum Kewarisan Hindu Yang Diresepir Ke Dalam Hukum Adat Di Bali Dan Lombok, Cet. I, Cv. Junasco.

Pudja dan sudharta, Tjokorda Rai, 1973, Manawadharmasastra, Surabaya: Paramita

Styady, Tolib, 2009, Intisari Hukum Adat Indonesia, Bandung: Alfabeta

Titib, I Made, 2003, Menumbuh kembangkan Pendidikan Budhi Pekerti Pada Anak (perspektif Agama Hindu), Bandung: Ganeca Exact.

Windia, P, Wayan dan Sudantra, 2006, Pengantar Hukum Adat Bali, Denpasar: Lembaga Dokumentasi dan Publikasi Fakultas Hukum Universitas Udayana

Zaini , Mudaris,1992, Adopsi Suatu Tinjauan dari Tiga Sistem Hukum, Jakarta: Sinar Grafika.

PERATURAN PERUNDANG-UNDANGAN

Undang-Undang No. 23 Tahun 2002, Tentang Perlindungan Anak.

\section{ARTIKEL}

https//paduarsana.com/2013/05/15.mengadopsianak-dalam perspektif-adat-bali

https://suryawanhinddharma.wordpress.com 